\title{
A Study of Prevalence and Pathogenic Activity of Bacteria in the Air of Dhaka City and Their Antimicrobial Resistance Pattern
}

\author{
Shaeri Nawar ${ }^{1,2}$, Maliha Tabassum Rashid ${ }^{1,2}$, Akash Ahmed ${ }^{3}$ (D), M. Mahboob Hossain ${ }^{3 *}$, \\ Asma Binte Afzal ${ }^{4}$ \\ ${ }^{1}$ Biotechnology, BRAC University, Dhaka, Bangladesh \\ ${ }^{2}$ Asian Network of Research on Antidiabetic Plants (ANRAP), Bangladesh University of Health Sciences, Mirpur, Dhaka, Bangladesh \\ ${ }^{3}$ Microbiology Program, BRAC University, Dhaka, Bangladesh \\ ${ }^{4}$ Department of Mathematics \& Natural Sciences, BRAC University, Dhaka, Bangladesh \\ Email: *mmhossain@bracu.ac.bd
}

How to cite this paper: Nawar, S., Rashid, M.T., Ahmed, A., Hossain, M.M. and Afzal, A.B. (2021) A Study of Prevalence and Pathogenic Activity of Bacteria in the Air of Dhaka City and Their Antimicrobial Resistance Pattern. American Journal of Molecular Biology, 11, 51-62.

https://doi.org/10.4236/ajmb.2021.112005

Received: February 27, 2021

Accepted: April 13, 2021

Published: April 16, 2021

Copyright $\odot 2021$ by author(s) and Scientific Research Publishing Inc. This work is licensed under the Creative Commons Attribution International License (CC BY 4.0).

http://creativecommons.org/licenses/by/4.0/

(c) (i) Open Access

\begin{abstract}
Bangladesh composes the most polluted air with Dhaka securing the top position. The purpose of the study is the enumeration of the prevalence of pathogenic bacteria in Dhaka city's air and their antibiotic susceptibility to the common antibiotics. For the sample collection, different selective media was exposed in air where the highest and lowest CFU was 137 and 1 respectively. Pathogens were screened through Hemolysis, DNase and Coagulase test and identified by $16 \mathrm{~s}$ rRNA sequencing followed by antibiotic susceptibility test. 16s rRNA sequencing revealed that the organisms were Bacillus altitudinis strain 41KF2bT.28, Bacillus licheniformis strain QMA46-2, Bacillus altitudinis, Bacillus pumilis strain BJ-DEBCR-34, Staphylococcus aureus strain TPS3156, Bacillus sp CO16, Pseudomonas sp strain 96LC22 and Shigella dysenteriae strain ATCC 13313. Shigella dysenteriae, Staphylococcus aureus were $81.81 \%$ and $54.54 \%$ resistant to the antibiotics. Whole-genome sequencing would help to observe mutations in the traits as changes in hemolytic activity were found during pathogenecity tests.
\end{abstract}

\section{Keywords}

16S rRNA Sequencing, Pathogenecity, Multi-Drug Resistant

\section{Introduction}

Ever since the COVID-19 outbreak, it has been of great concern to identify the pathogens in nature and hence the atmosphere. Microorganisms like viruses and bac- 
teria are known to have been co-existing in nature with us from the beginning of life [1]. In this era of incidences, epidemics, and pandemics which are most likely to be transmitted through air or atmosphere, it is of great significance to identify the potential pathogens in the air and take necessary measures as soon as possible.

A new study suggests that Bangladesh composes the most polluted air with Dhaka securing the second position in terms of pollution [2]. According to IQ AirVisual 2019 reports, Dhaka city is ranked number 21st amongst the world's most polluted cities [3]. However, this study aimed to enumerate the prevalence of the microorganisms present in the air of Dhaka city to get an idea of the kind of pathogenic bacteria present in such an extremely polluted area. Every day, 14 $\mathrm{m}^{3}$ of air is inhaled by a person [4] [5]. If there are numerous pathogenic microbes in the air that people inhale, it could be health hazardous for them. Some pathogenic strains in the air and their chemical secretions have the potential to bring about acute health disorders and cause infectious diseases [4] [6]. Therefore, it is of great significance to enumerate the pathogenic microbes present in the air we breathe in and their hazardous effect and disease-causing capability, which is the pathogenicity. The fact that a pathogenic microbe would survive or not depends on their resistance capacity and the environmental conditions [7]. The study aims to find out pathogens in the air and confirm the pathogenic strain species through genetic analysis of $16 \mathrm{~S}$ rRNA gene sequences. Side by side the study also depicts the multidrug resistance of the prevalent microbes in the air. In addition to that, a comparison of colony count which shows the highest number of colonies and the lowest number recorded.

\section{Materials and Methods}

\subsection{Study Area}

This study was carried in different zones around Dhaka city (the Capital of Bangladesh) from January 2019 to October 2019. The laboratory work was conducted at the Microbiology Research Laboratory of the Department of Mathematics and Natural Sciences of BRAC University.

Figure 1 shows locations covered in Dhaka city for microbial sample collection in a map form. The areas are, 1) Mohakhali, 2) Gulshan, 3) Banani, 4) Mirpur, 5) Farmgate, 6) Dhanmondi, 7) Uttara. Among these areas around Dhaka city, Farmgate and Mohakhali are the major transportation hubs from where people travel around the city. These areas are always crowded and consist of numerous open garbage stations and drain and also pollution from public toilets. Banani and Gulshan are solely residential areas as these are the home to several commercial buildings, schools, universities, shopping centers, etc. Air samples were taken from these two areas to find potential pathogenic microbes. Mirpur has a significant number of garment factories which make this area highly polluted. Deadly wastages of garments are dumped openly which may help hazardous microbes to grow onto them and spread through the air. However, Uttara is also a busy location where Hazrat ShahJalal International Airport 
Location of Sample Collection Sites within Dhaka City

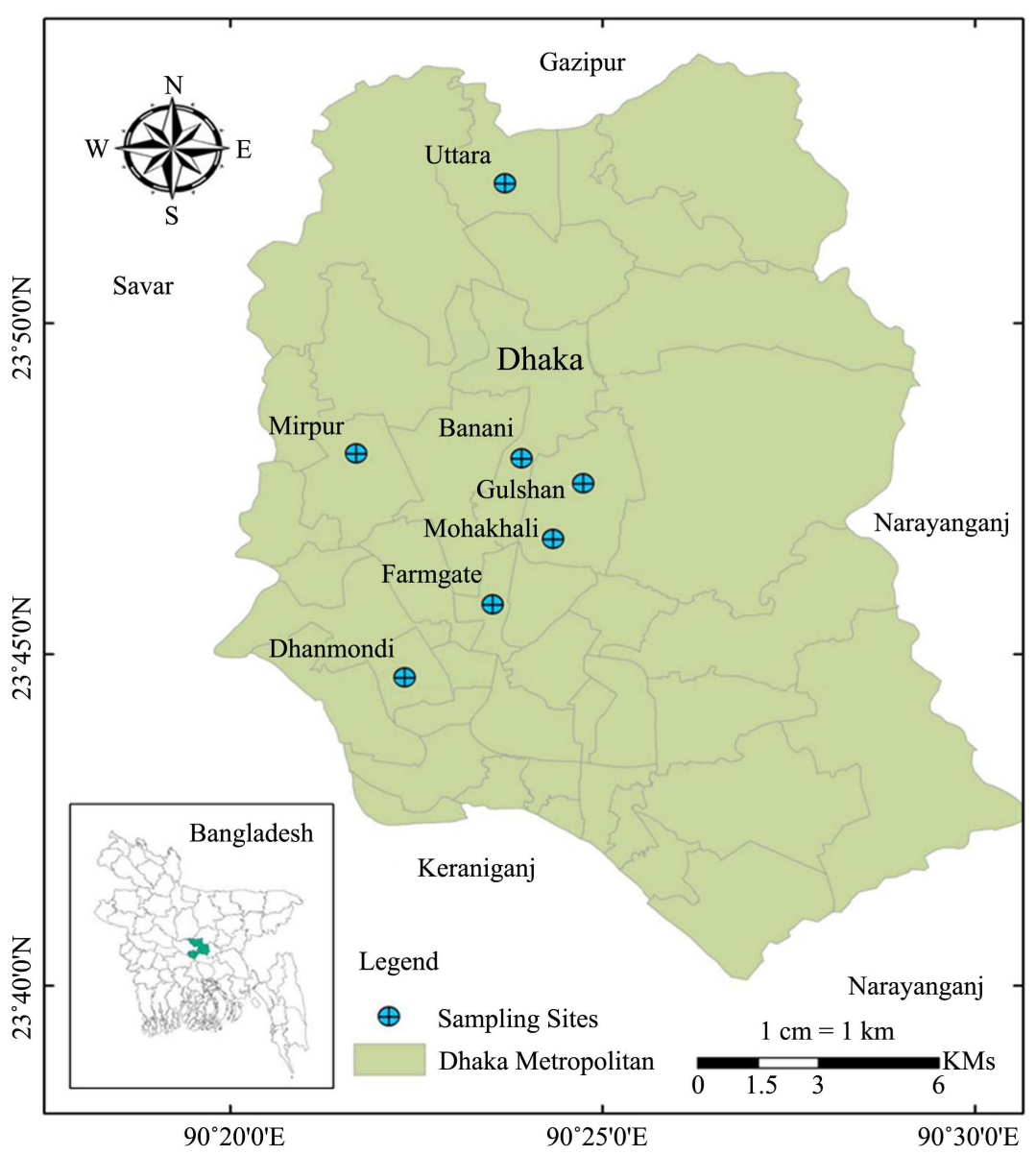

Figure 1. Sample area map.

(the biggest airport in Bangladesh) and Airport Railway Station is located. Dhanmondi has a large number of schools, hospitals, and shopping malls, etc. All these places are very important central business zones and the most crowded sites around Dhaka city and that is why they were selected for air sampling.

\subsection{Air Sampling and Microbiological Analysis}

Air samples were collected applying plate sedimentation technique as applied by Stryjakowska-Sekulska et al., 2007 and Ekhaise et al., 2008 [6] [8]. The plate sedimentation methods were used by opening prepared Petri dishes containing Nutrient agar, Mannitol salt agar, and Mac Conkey agar for collecting culturable microbes that are present in the air. Petri dishes were exposed to outdoor air in two different time intervals ( 2 minutes and 5 minutes). Immediately after exposure, the Petri dishes were transferred to the laboratory for further microbiological analysis. The Petri dishes were incubated at $37^{\circ} \mathrm{C}$ for $24-48$ hours.

\subsection{Hemolytic Activity Identification}

Hemolysis occurs when the erythrocytes in the blood rupture and discharge 
hemoglobin. Pathogenic bacteria produce hemolysins, a toxin that damages the cytoplasmic membranes in red blood cells and causes lysis or cell death [9]. Blood Agar plates were prepared from the Tryptic Soy Agar base with 5\% sheep blood for the detection of pathogenic bacteria. Selective cultured bacteria were screened on the blood agar base and incubated for 24 hours. Following the next day, hemolytic activity was observed by holding up the plate to a light source with the light coming from backward [10]. Isolates that had shown hemolytic properties were marked as potential pathogens and went for further study.

\subsection{Dnase Agar Test and Coaglulase Test}

DNase agar base, a differential medium was used to test the ability of a micro- organism to produce deoxyribonuclease or DNase. Pathogenic organisms can hydrolyze DNA on the DNase agar plate and utilize it as a source of energy for growth. This Dnase agar medium base is generally pale blue because of Toluidine Dye (indicator) complex. It also contains nutrients for the bacteria. After the inoculation of the organism in the agar base, if the organism that grows in the medium produces Deoxyribonuclease, it is broken down into smaller fragment molecules. When the DNA is broken down, it no longer binds to the Toluidine blue, and blue color fades and the colony is surrounded by a colorless clear zone.

On the contrary the coagulase is an exoenzyme, produced during coagulase test which causes the fibrin (protein formed from fibrinogen) of blood plasma to clot. Human blood collected from blood banks is generally avoided because it has variable amounts of CRF (coagulase clumping factor) and anti-staphylococcal antibodies which are not recommended to use [11]. Rabbit blood was used in this study to make the plasma for the coagulase test. Fresh cultured samples were inoculated on clean slides, then re-suspended in $2 \mathrm{ml}$ of rabbit blood plasma and examined a few hours later.

\subsection{Bacterial DNA Isolation, PCR Amplification and Agarose Gel Electrophoresis}

Bacterial DNA isolation has been done for bacterial isolates by the standard boiling method. PCR was done following Standard protocol for PCR [12].

The PCR reaction products were visualized at $1 \%$ of agarose gel under the ultraviolet (UV) light after stained by ethidium bromide [13] [14].

\subsection{PCR Product Purification}

The PCR products of the 16S rRNA gene were purified using Thermo Scientific GeneJET PCR Purification Kit (Thermo Fisher Scientific).

\subsection{S rRNA Sequencing and Bacterial Species Identification Using BLAST}

Purified PCR products were sent to Invent Technologies Ltd., Dhaka for $16 \mathrm{~S}$ rRNA gene sequencing. 
The generated $16 \mathrm{~S}$ rRNA sequences were analyzed at the NCBI server at BLAST (Basic Alignment Searched Tool) N-site. In comparison, the closest related species were compared with percentages of identity.

\subsection{Antibiotic Susceptibility Test}

Identified bacterial isolates were subjected to antibiotic susceptibility testing by Kirby Bauer's disc diffusion method following CLSI (Clinical and Laboratory Standards Institute) guidelines [15]. The organisms were screened against eleven common antibiotics for their antibiotic susceptibility test; they are Tetracycline $30 \mu \mathrm{g}$, Moxifloxacin $5 \mu \mathrm{g}$, Doxycycline $30 \mu \mathrm{g}$, Ciprofloxacin $5 \mu \mathrm{g}$, Levofloxacin 5 $\mu \mathrm{g}$, Amoxiclav $30 \mu \mathrm{g}$, Chloramphenicol $30 \mu \mathrm{g}$, Penicillin $10 \mu \mathrm{g}$, Cefixime $5 \mu \mathrm{g}$, Azithromycin $10 \mu \mathrm{g}$, and Cefuroxime $30 \mu \mathrm{g}$.

\section{Results}

The results of hemolysis by screening seventy-four different strains which were characterized by their morphology, eight of them have shown beta-hemolytic activity on blood agar and sixty-eight have shown gamma hemolysis (no hemolysis).

All beta-hemolytic isolates were marked as potential pathogens. DNase agar test and coagulase tests were performed on the eight beta-hemolytic isolates.

Figure 2 depicts the beta hemolytic activity of two air samples 2 min MSA1 Banani and 5 min NA1 Banani.

Table 1 shows that among eight isolates, three of them have produced deoxyribonuclease (DNase) which hydrolyzed DNA on the agar plate by showing a clear zone around. These have shown positive results on the DNase agar test. Three of the isolates have shown the coagulase test positive by showing coagulase reaction (clumps are seen). Only one organism was found to be both DNase, and coagulase-positive.

Following in the further study, $16 \mathrm{~S}$ rRNA sequencing was done for the eight microbes that showed pathogenic properties (Beta hemolytic) in blood agar.

Table 1. Hemolysis, DNase, and Coagulase test results of the isolate.

\begin{tabular}{cclc}
\hline No. & Test strains & Hemolysis type & DNase agar test \\
\hline 1 & 2 min MSA1 Banani & Beta hemolytic & negative \\
2 & 5 min NA1 Banani & Beta hemolytic & negative \\
3 & 5 min NA4 Mirpur & Beta hemolytic & negative \\
4 & 2 min NA1Farmgate & Beta hemolytic & negative \\
5 & 5 min NA3 Mirpur & Beta hemolytic & positive \\
6 & 5 min NA1 Uttara & Beta hemolytic & negative \\
7 & 5 min MAC1 Banani & Beta hemolytic & positive \\
8 & 5 min NA1 Mirpur & Beta hemolytic & positive \\
\hline
\end{tabular}

*MSA-Mannitol salt agar, NA-Nutrient agar, MAC-Mac conkey agar, 2MIN and 5MIN-petri dishes exposure time. 

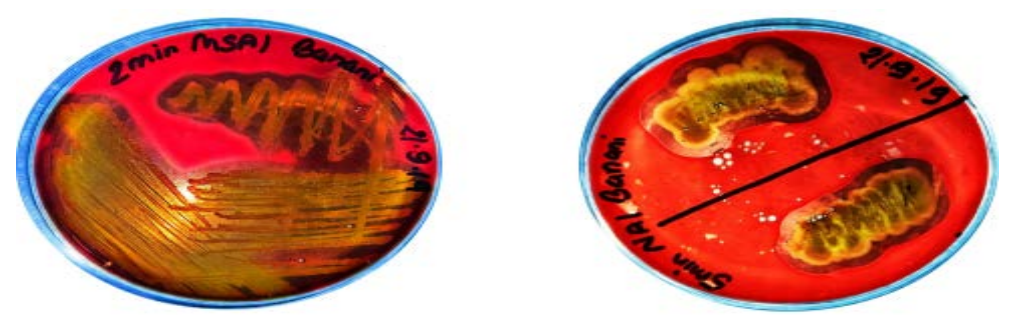

Figure 2. Bacteria showing beta hemolysis on blood agar plates.

Table 2 shows the closest related species of the air samples through 16S rRNA sequencing. From here we can see 2 min MSA1 Banani, 5 min NA1 Banani, 2 min NA1 Farmgate, 5 min MAC1 Banani and 5 min NA1 Mirpur were 99\% $100 \%$ similar to Bacillus altitudinis strain 41KF2bT.28, Bacillus licheniformis strain QMA46-2, Bacillus pumilis strain BJ-DEBCR-34, Pseudomonas sp strain 96LC22 and Shigella dysenteriae strain ATCC 13313. Other three organisms 5MIN NA4 Mirpur, 5MIN NA3 Mirpur and 5MIN NA1 Uttara show 100\% similarity to Bacillus altitudinis, Staphylococcus aureus strain TPS3156 and Shigella dysenteriae strain ATCC 13313.

\section{Antimicrobial Resistance}

Eight pathogenic isolates named Bacillus altitudinis strain 41KF2bT.28, Bacillus licheniformis strain QMA46-2, Bacillus altitudinis, Bacillus pumilis strain BJDEBCR-34, Staphylococcus aureus strain TPS3156, Bacillus sp CO16, Pseudomonas sp strain 96LC22, and Shigella dysenteriae strain ATCC 13313 were subjected to eleven commonly used antibiotics for an antibiotic susceptibility test.

In Table 3, two of the pathogens namely Staphylococcus aureus strain TPS3156 and Shigella dysenteriae strain ATCC 13313 were found to be $54.54 \%$ and $81.81 \%$ resistant to 6 drugs (Azithromycin $10 \mu \mathrm{g}$, Tetracycline $30 \mu \mathrm{g}$, Penicillin $30 \mu \mathrm{g}$, Cefixime $5 \mu \mathrm{g}$, Doxycycline $30 \mu \mathrm{g}$, Cefuroxime $30 \mu \mathrm{g}$ ) and 9 drugs (Tetracycline $30 \mu \mathrm{g}$, Penicillin $30 \mu \mathrm{g}$, Cefixime $5 \mu \mathrm{g}$, Moxifloxacin $5 \mu \mathrm{g}$, Doxycycline 30 $\mu \mathrm{g}$, Ciprofloxacin $5 \mu \mathrm{g}$, Chloramphenicol $30 \mu \mathrm{g}$, Amoxiclav $30 \mu \mathrm{g}$, Cefuroxime 30 $\mu \mathrm{g})$.

\section{Discussion}

According to a report of WHO in 2014, in the year 2012, 2.6 million deaths were likely to be caused due to outdoor air pollution [16]. This scenario was most prevalent in the South-east Asian countries and the Western Pacific countries because these are the developing countries where industrialization following air pollution is high with low to middle-income rates [17]. Over the last few years, Bangladesh is facing a concerning number of air pollution deaths with 173,500 deaths in 2019 [18]. However, in our study, the air sample collection zones were chosen to cover most important and crowded areas of Dhaka city. Eight pathogens were found which reveal early signs of being potential health hazards of the environment. 
Table 2. 16S rRNA sequencing results of the eight beta hemolytic pathogens.

\begin{tabular}{|c|c|c|c|c|}
\hline Test strain & Sequences similar to & Similarity & E-Value & $\begin{array}{c}\text { NCBI } \\
\text { Accession No }\end{array}$ \\
\hline $\begin{array}{c}2 \text { min MSA1 } \\
\text { Banani }\end{array}$ & Bacillus altitudinis strain $41 \mathrm{KF} 2 \mathrm{bT} .28$ & $99 \%-100 \%$ & 0.0 & MN543872.1 \\
\hline $\begin{array}{c}5 \text { min NA1 } \\
\text { Banani }\end{array}$ & Bacillus licheniformis strain QMA46-2 & $99 \%-100 \%$ & 0.0 & MT525234.1 \\
\hline $\begin{array}{l}5 \text { min NA4 } \\
\text { Mirpur }\end{array}$ & Bacillus altitudinis & $100 \%$ & 0.0 & MT627439.1 \\
\hline $\begin{array}{l}2 \text { min NA1 } \\
\text { Farmgate }\end{array}$ & Bacillus pumilis strain BJ-DEBCR-34 & $99 \%-100 \%$ & 0.0 & MF487832.1 \\
\hline $\begin{array}{l}5 \text { min NA3 } \\
\text { Mirpur }\end{array}$ & Staphylococcus aureus strain TPS3156 & $100 \%$ & 0.0 & AP023034.1 \\
\hline $\begin{array}{c}5 \text { min NA1 } \\
\text { Uttara }\end{array}$ & Bacillus sp $\mathrm{CO} 16$ & $100 \%$ & 0.0 & DQ643042.1 \\
\hline $\begin{array}{c}5 \text { MIN } \\
\text { MAC1 Banani }\end{array}$ & Pseudomonas sp strain 96LC22 & $99 \%-100 \%$ & 0.0 & MT072158.1 \\
\hline $\begin{array}{l}5 \text { min NA1 } \\
\text { Mirpur }\end{array}$ & Shigella dysenteriae strain ATCC 13313 & $99 \%-100 \%$ & 0.0 & NR 026332.1 \\
\hline
\end{tabular}

${ }^{*} 2 \mathrm{MIN}$ and $5 \mathrm{MIN}=$ two time intervals of sample collection, MSA-Mannitol Salt Agar, NA-Nutrient Agar, MAC-Mac Conkey Agar.

Table 3. Resistance pattern of bacterial isolates.

\begin{tabular}{|c|c|c|c|c|c|c|c|c|c|}
\hline $\begin{array}{l}\text { S. } \\
\text { No. }\end{array}$ & Isolate strain & $\begin{array}{l}\text { AZM } \\
10 \mu g\end{array}$ & $\begin{array}{c}\text { TE } \\
30 \mu \mathrm{g}\end{array}$ & $\begin{array}{l}\text { PEN } \\
30 \mu \mathrm{g}\end{array}$ & $\begin{array}{l}\text { CFM } \\
5 \mu \mathrm{g}\end{array}$ & $\begin{array}{r}\text { MXF } \\
5 \mu \mathrm{g}\end{array}$ & $\begin{array}{c}\mathrm{DO} \\
30 \mu \mathrm{g}\end{array}$ & $\begin{array}{l}\text { CIP } \\
5 \mu \mathrm{g}\end{array}$ & $\begin{array}{l}\mathrm{LE} \\
5 \mu \mathrm{g}\end{array}$ \\
\hline 1 & $\begin{array}{l}\text { Bacillus altitudinis } \\
\text { strain } 41 \mathrm{KF} 2 \mathrm{bT} .28\end{array}$ & $S$ & S & S & $\mathrm{R}$ & S & S & S & S \\
\hline 2 & $\begin{array}{l}\text { Bacillus licheniformis } \\
\text { strain QMA46-2 }\end{array}$ & S & S & S & $\mathrm{R}$ & S & S & S & S \\
\hline 3 & Bacillus altitudinis & IR & $S$ & $\mathrm{R}$ & $\mathrm{R}$ & S & S & S & S \\
\hline 4 & $\begin{array}{l}\text { Bacillus pumilis strain } \\
\text { BJ-DEBCR-34 }\end{array}$ & $S$ & $S$ & $S$ & $\mathrm{R}$ & $S$ & $S$ & $S$ & $S$ \\
\hline 5 & $\begin{array}{l}\text { Staphylococcus aureus } \\
\text { strain TPS3156 }\end{array}$ & $\mathrm{R}$ & $\mathrm{R}$ & $\mathrm{R}$ & $\mathrm{R}$ & IR & $\mathrm{R}$ & S & S \\
\hline 6 & Bacillus sp $\mathrm{CO} 16$ & S & S & S & $\mathrm{R}$ & S & S & S & S \\
\hline 7 & $\begin{array}{l}\text { Pseudomonas } s p \\
\text { strain 96LC22 }\end{array}$ & $S$ & $S$ & $\mathrm{R}$ & $\mathrm{R}$ & S & S & $\mathrm{R}$ & $S$ \\
\hline 8 & $\begin{array}{l}\text { Shigella dysenteriae } \\
\text { strain ATCC } 13313\end{array}$ & IR & $\mathrm{R}$ & $\mathrm{R}$ & $\mathrm{R}$ & $\mathrm{R}$ & $\mathrm{R}$ & $\mathrm{R}$ & S \\
\hline
\end{tabular}

*AZM-Azithromycin, TE-Tetracycline, PEN-Penicillin, CFM-Cefixime, MXF-Moxifloxacin, DO-Doxycycline, CIP-Ciprofloxacin, Le-Levofloxacin, C-Chloramphenicol, AMC-Amoxiclav, CXM-Cefuroxime, S-Sensitive, R-Resistant, IR-Intermediate Resistant.

One of the most alarming findings of our study was Shigella, which is the causative agent of a kind of diarrheal disease called shigellosis which transmits through direct exposure of the microbe present in feces or consumption of con- 
taminated water and meal. Generally, in blood agar media, Shigella dysenteriae shows gamma or no hemolysis at all [19] but in our study, Shigella showed beta hemolysis. This could be due to some mutation in the genetic makeup of the strain found in air that possess potential pathogenic characteristics. The more concerning fact is that the strain is multi-drug resistant. This is alarming because if a pathogenic and multidrug resistant strain of Shigella is in the air then it can cause disease through a novel route of transmission.

Secondly, the most frequently occurring bacteria of the staphylococcal family, Staphylococcus aureus is also the most pathogenic in which skin, heart valve, and bone infections and pneumonia are predominant. Staphylococcus aureus typically gives $\beta$-hemolytic phenotype [20] and our Staphylococcus aureus strain TPS3156 also showed the same. Besides the strain was Coagulase and DNase positive. Despite being highly pathogenic, the alarming fact here is that the strain was resistant to majority of the common antibiotics used in the experiment to see antibiotic susceptibility pattern. So, the antibiotic resistant gene must be detected to find out presence of mutation and act accordingly.

The third pathogen was Bacillus altitudinis strain 41KF2bT.28. According to Kaur \& Goyal, 2020 "Butachlor is a chloroacetamide pre-emergence herbicide. It has been speculated as a carcinogen, genotoxin, neurotoxin, and present firmly in the environment having a toxic effect on living systems". A Butachlor degrading bacterial strain A16 was isolated from coal tar contaminated soil [21]. In our study, 16S rRNA analysis revealed $99.38 \%$ resemblance of butachlor degrading strain A16 with Bacillus altitudinis 41KF2bT strain which suggests the strain could have the characteristics of degrading butachlor too. Evidently butachlor is a genotoxin so it might have changed the genetic makeup of the Bacillus altitudinis strain $41 \mathrm{KF} 2 \mathrm{bT} .28$ while degrading it causing the strain to mutate and act as a pathogen by showing hemolytic activity which is not its usual characteristic. However, another same bacterial strain found in our research is $B$. altitudinis. A study shows that $B$. altitudinis A-19 16S strain gives partial hemolytic activity in salted fish L. vivanus in Indonesia [22]. In our study, it showed total beta hemolysis and hence a suggested potential pathogen. Now the question arises as it is already showing pathogenic characteristics, does it have the capacity to transmit to humans and cause disease? The answer lies in further investigation on this strain.

People who are unable to develop normal immune responses may suffer from infections caused by Bacillus licheniformis making the bacteria a potential human pathogen. However, a case has been recorded of a patient with a competent immune system being diagnosed with sepsis caused by B. licheniformis where antibiotic treatment did not work [23]. Another research shows for the first time, a unilateral maxillary sinusitis case was reported that was caused by $B$. licheniformis and that too in a patient with a competent immune system [24]. The strain of B. licheniformis that was found in the air of the Banani area of Dhaka showed beta hemolysis in blood agar. Usually, B. licheniformis shows no hemolytic activities [25] but in our experiment, it showed beta hemolysis which being 
a potential pathogen in the air is highly exposed to humans and could be a causative agent of multiple infections.

B. pumilis does not cause infection very often except in cases of people with suppressed immunity and neonates mostly as skin infections. However a case of septic arthritis with the causative agent, $B$. pumulis was reported in a healthy boy [26]. The B. pumulis in our experiment showed pathogenicity with beta hemolysis in blood agar but in general, it also shows beta hemolysis in blood agar. We believe' B. pumilus in the air may cause human to human transmissive infections. This could be assumed from a study, where Bacillus pumilus was the causative agent of a kind of cutaneous infection whose lesions were identical to those of cutaneous anthrax lesions [27].

In our study, Bacillus sp. CO16 showed beta hemolysis hence pathogenicity along with being resistant to Cefixime $5 \mu \mathrm{g}$ and Cefuroxime $30 \mu \mathrm{g}$. There is no conventional data available that suggests Bacillus sp. CO16 is a pathogen but it showed beta hemolysis in our experiment that depicts pathogenicity which could be due to possible mutation.

Pseudomonas stutzeri is a rare opportunistic pathogen isolated from human CSF (cerebrospinal fluid) which was found in people undergoing CAPD (continuous ambulatory peritoneal dialysis) [28]. Our experiment found Pseudomonas $s p$ strain $96 \mathrm{LC} 22$ is a potential pathogen found in air which is not commonly studied bacteria but could be compared to $P$. stutzeri because their 16srRNA sequencing result shows most similarity and so it might pose opportunistic pathogenic characteristic after having mutation. Further study of this strain is required.

Some studies on the identification of air microbes have been conducted from time to time covering smaller areas in Bangladesh. Two studies by Kabir et al., 2016 and Uddin et al., 2020 was done in university premises in which prevalence and identification of the bacteria was seen but no pathogenicity and antimicrobial resistance was performed [4] [29]. Another study by Asaduzzaman et al., 2019 which is ongoing where airborne antibiotic-resistant bacteria were targeted to help form data for multidrug-resistant pathogens but no pathogenicity or identification was done here [30]. On the other hand, our study narrowed down the pathogens first and then figured out which pathogenic strain is multi-drug resistant. As a result, possible health hazardous pathogenic strains that are multidrug-resistant were specifically detected. A wider area wise pathogenic identification following their antibiotic resistance to shedding light on the total pathogenic microbial state of the busiest area of Dhaka city has been done for the first time in Bangladesh.

\section{Conclusion}

It is quite alarming that these proven pathogens are found in the air and some of them show resistance to a number of commonly used antibiotics and people are highly exposed to it. Hence extending the work would help us find out the po- 
tential pathogens dispersed in the environment and act on time before the matter gets out of hand and give rise to new incidences, epidemics, or even pandemics. Mutated characteristics might be present among all of the eight microbes for which whole-genome sequencing is a must to find out the mutation in the strain. The virulence activity of pathogens could be detected too along with its course of transmission. The research could be termed as a potential environmental hazard issue as certain and further studies related to it could be conducted shortly.

\section{Acknowledgements}

We thank all the staff of the microbiology laboratory of BRAC University for their help and collaboration in the development of this study. We also extend our gratitude to INVENT Technologies LTD. for 16S rRNA sequencing.

\section{Conflicts of Interest}

The authors of this research article declare no conflict of interest, financial or otherwise.

\section{References}

[1] Moore, M.D. and Jaykus, L.A. (2018) Virus-Bacteria Interactions: Implications and Potential for the Applied and Agricultural Sciences. Viruses, 10, 61.

https://doi.org/10.3390/v10020061

[2] Al-Masum Molla, M. (2019) Living in Toxic Air. The Daily Star. https://www.thedailystar.net/frontpage/dhaka-second-most-polluted-air-city-in-wo rld-living-toxic-air-1711213

[3] (2019) World Most Polluted Cities in 2019. IQAir. https://www.iqair.com/world-most-polluted-cities? continent $=\&$ country $=\&$ state $=\& p$ age $=1 \&$ perPage $=50 \&$ cities $=$ vnxvinME52 $\mathrm{vNycse} 5$

[4] Kabir, M.S., Mridha, F., Islam, S. and Shorifujjaman, M. (2016) Microbiological Pollutants in Air and Antibiotic Resistance Profile of Some Bacterial Isolates. Jahangirnagar University Journal of Biological Sciences, 5, 47-56. https://doi.org/10.3329/jujbs.v5i1.29742

[5] Brochu, P., Ducré-Robitaille, J.-F. and Brodeur, J. (2006) Physiological Daily Inhalation Rates for Free-Living Individuals Aged 1 Month to 96 Years, Using Data from Doubly Labeled Water Measurements: A Proposal for Air Quality Criteria, Standard Calculations and Health Risk Assessment. Human and Ecological Risk Assessment: An International Journal, 12, 675-701. https://doi.org/10.1080/10807030600801550

[6] Stryjakowska-Sekulska, M., Piotraszewska-Pajak, A., Szyszka, A., Nowicki, M. and Filipiak, M. (2007) Microbiological Quality of Indoor Air in University Rooms. Polish Journal of Environmental Studies, 16, 623-632.

[7] Cernei, E.R., Maxim, D.C., Mavru, R. and Indrei, L.L. (2013) Bacteriological Analysis of Air (Aeromicroflora) from the Level of Dental Offices in Iaşi County. Romanian Journal of Oral Rehabilitation, 5, 53-58.

[8] Ekhaise, F.O., Ighosewe, O.U. and Ajakpovi, O.D. (2008) Hospital Indoor Airborne Microflora in Private and Government Owned Hospitals in Benin City, Nigeria. 
World Journal of Medical Sciences, 3, 19-23.

[9] Hemolysis (2020) VetBact.

https://www.vetbact.org/index.php?displayextinfo=67\&vbsearchstring=Hemolytic\% 20activitym

[10] Buxton (2005) Blood Agar Plates and Hemolysis Protocols. American Society for Microbiology, 1-9.

https://asm.org/getattachment/7ec0de2b-bb16-4f6e-ba07-2aea25a43e76/protocol-28 $\underline{85 . p d f}$

[11] Koneman, E.W.A.S. (1997) The Gram Positive Cocci: Staphylococci and Related Organism. In Color Atlas and Textbook of Diagnostic Microbiology.

[12] Standard Protocol for PCR, Lee Lab 016 (2014) Department of Microbiology, Technische Universität München.

http://www.microbial-systems-ecology.de/pdf files/standardPCR 13jan2014.pdf

[13] da Silva, R.B. and Valicente, F.H. (2013) Molecular Characterization of Bacillus thuringiensis Using rep-PCR. SpringerPlus, 2, 641. https://doi.org/10.1186/2193-1801-2-641

[14] Devereux, R. and Willis, S.G. (1995) Amplification of Ribosomal RNA Sequences. In: Akkermans, A.D.L., Van Elsas, J.D. and De Bruijn, F.J., Eds., Molecular Microbial Ecology Manual, Springer, Dordrecht, 277-287.

https://doi.org/10.1007/978-94-011-0351-0 19

[15] Hudzicki, J. (2009) Kirby-Bauer Disk Diffusion Susceptibility Test Protocol. American Society for Microbiology.

[16] World Health Organisation (WHO) (2014) Burden of Disease from Air Pollution. http://www.who.int/phe/health topics/outdoorair/databases/FINAL HAP AAP B oD 24March2014.pdf?ua=1

[17] Kelly, F.J. and Fussell, J.C. (2015) Air Pollution and Public Health: Emerging Hazards and Improved Understanding of Risk. Environmental Geochemistry and Health, 37, 631-649. https://doi.org/10.1007/s10653-015-9720-1

[18] (2020) Death Toll from Air Pollution Sees Alarming Rise in Bangladesh. Dhaka Tribune.

https://www.dhakatribune.com/bangladesh/2020/10/21/death-toll-from-air-pollutio n-sees-alarming-rise-in-bangladesh

[19] Batra, S. (2018) Morphology and Culture Characteristics of Shigella dysenteriae (Sh. dysenteriae). Paramedics World.

https://paramedicsworld.com/shigella-dysenteriae/morphology-culture-characterist ics-of-shigella-dysenteriae/medical-paramedical-studynotes

[20] Zhang, H. (2016) Identification and Characterization of Staphylococcus aureus Strains with an Incomplete Hemolytic Phenotype. Frontiers.

https://www.frontiersin.org/articles/10.3389/fcimb.2016.00146/full https://doi.org/10.3389/fcimb.2016.00146

[21] Kaur, R. and Goyal, D. (2020) Biodegradation of Butachlor by Bacillus altitudinis and Identification of Metabolites. Current Microbiology, 77, 2602-2612. https://doi.org/10.1007/s00284-020-02031-1

[22] Aziz, I.R., et al. (2019) Identification of Pathogenic Bacteria on the Salted Fish Lutjanus vivanus in Sorong City of West Papua. Malaysian Journal of Microbiology, 15, 237-244. https://doi.org/10.21161/mjm.180230

[23] Haydushka, I.A., Markova, N., Kirina, V. and Atanassova, M. (2012) Recurrent Sepsis Due to Bacillus licheniformis. Journal of Global Infectious Diseases, 4, 82-83. https://doi.org/10.4103/0974-777X.93768 
[24] Garcia Hejl, C., Sanmartin, N., Samson, T., Soler, C. and Koeck, J.L. (2015) Maxillary Sinus Infection by Bacillus licheniformis. A Case Report from Djibouti. Médecine et Santé Tropicales, 25, 220-221. https://doi.org/10.1684/mst.2015.0470

[25] (2020) Bacillus licheniformis. VetBact. http://www.vetbact.org/index.php?artid=12

[26] Shivamurthy, V.M., Gantt, S., Reilly, C., Tilley, P., Guzman, J. and Tucker, L. (2016) Bacillus pumilus Septic Arthritis in a Healthy Child. Canadian Journal of Infectious Diseases and Medical Microbiology, 2016, Article ID: 3265037. https://doi.org/10.1155/2016/3265037

[27] Tena, D., Martinez-Torres, J., Perez-Pomata, M.T., Saez-Nieto, J.A., Rubio, V. and Bisquert, J. (2007) Cutaneous Infection Due to Bacillus pumilus: Report of 3 Cases. Clinical Infectious Diseases, 44, e40-e42. https://doi.org/10.1086/511077

[28] Park, S.W., Back, J.H., Lee, S.W., Song, J.H., Shin, C.H., Kim, G.E. and Kim, M.J. (2013) Successful Antibiotic Treatment of Pseudomonas stutzeri-Induced Peritonitis without Peritoneal Dialysis Catheter Removal in Continuous Ambulatory Peritoneal Dialysis. Kidney Research and Clinical Practice, 32, 81-83. https://doi.org/10.1016/j.krcp.2013.04.004

[29] Uddin, M.N., Latifa, G.A., Majumder, A.K., Shamsi, S. and Nayeem, A.A. (2020) Analysis of Ambient Airborne Mycoflora around Curzon Hall Campus, University of Dhaka, Bangladesh. Stamford Journal of Microbiology, 9, 32-35. https://doi.org/10.3329/sjm.v9i1.45656

[30] Asaduzzaman, M., Hossain, M.I., Saha, S.R., Islam, M.R., Ahmed, N. and Islam, M.A. (2019) Quantification of Airborne Resistant Organisms with Temporal and Spatial Diversity in Bangladesh: Protocol for a Cross-Sectional Study. JMIR Research Protocols, 8, e14574. https://doi.org/10.2196/14574 